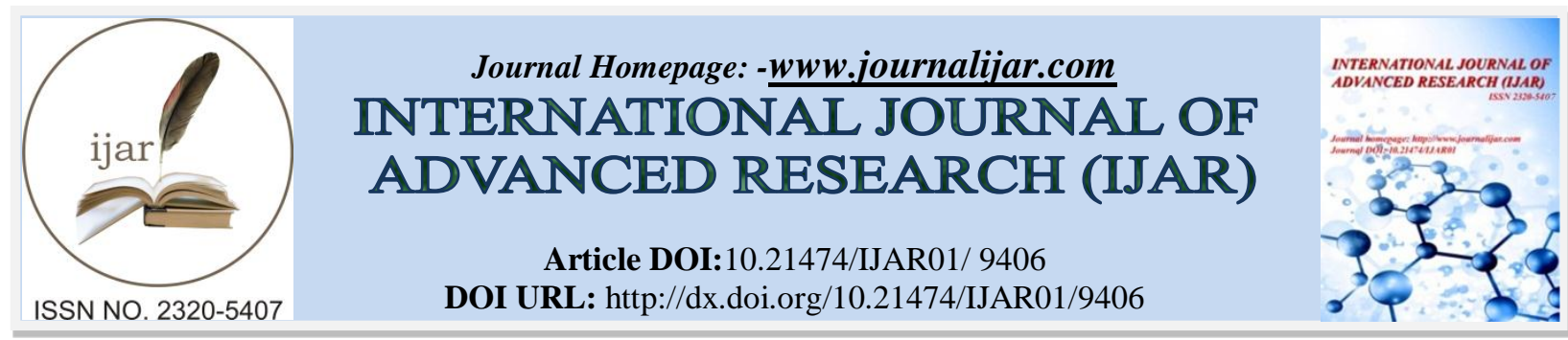

RESEARCH ARTICLE

\title{
ASSOCIATION BETWEEN GUT BRAIN AXIS AND VARIOUS DISORDERS - A LITERATURE REVIEW.
}

\section{Muthukumaran Jothilingam ${ }^{1}$, K.Kotteeswaran' ${ }^{2}$, M.Manikumar ${ }^{2}$, Jagatheesan Alagesan $^{3}$ and S.Bakiyalakshmi ${ }^{4}$.}

1. Assistant Professor, Saveetha College of Physiotherapy, Saveetha Institute of Medical and Technical Sciences, Chennai, India.

2. Associate professor, Saveetha College of Physiotherapy, Saveetha Institute of Medical and Technical Sciences, Chennai, India.

3. Professor \& Principal, Saveetha College of Physiotherapy, Saveetha Institute of Medical and Technical Sciences, Chennai, India.

4. Clinical Physiotherapist, Saveetha College of Physiotherapy, Saveetha Institute of Medical and Technical Sciences, Chennai, India.

\section{Manuscript Info}

Manuscript History

Received: 20 May 2019

Final Accepted: 22 June 2019

Published: July 2019

Key words:-

Microbiota, Gut Brain Axis, Autism,

Parkinson's Disease, Schizophrenia.

\section{Abstract}

Aim: The aim of this review is to identify and summarize the existing evidences on association between gut brain axis and various disorders. Method: Research studies will be obtained from various data bases through computer based search in Pubmed, google scholar, Embase, and Cochrane. Obtained studies will be short listed according to inclusion criteria and its results will be reviewed and presented.

Result: A total of 20 studies were potentially identified by the authors. Studies published in English language were included in this review. Conclusion: The gut microbe has been identified as the main source of highest biological variability confined in an individual and also provides constant antigenic stimulation shaping up the physiological immune response.

Copy Right, IJAR, 2019,. All rights reserved.

\section{Introduction:-}

The gut-brain axis is the biochemical signaling that takes place between the gastrointestinal tract and the central nervous system.. ${ }^{[1]}$ Broadly defined, the gut-brain axis includes the central nervous system, neuroendocrine and neuroimmune systems including the hypothalamic-pituitary-adrenal axis (HPA axis), sympathetic and parasympathetic arms of the autonomic nervous system including the enteric nervous system and the vagus nerve, and the gut microbiota. ${ }^{[1][3]}$ The enteric nervous system has been described as a "second brain". ${ }^{[5]}$ The enteric nervous system can operate autonomously. ${ }^{[5]}$ It normally communicates with the central nervous system (CNS) through the parasympathetic (e.g., via the vagus nerve) and sympathetic (e.g., via the prevertebral ganglia) nervous systems. ${ }^{[5]}$ Gut microorganisms benefit the host by collecting the energy from the fermentation of undigested carbohydrates and the subsequent absorption of short-chain fatty acids (SCFAs), acetate, butyrate, and propionate.$^{[4][7]}$ Intestinal bacteria also play a role in synthesizing vitamin $\mathrm{B}$ and vitamin $\mathrm{K}$ as well as metabolizing bile acids, sterols, and xenobiotics. ${ }^{[7]}$ The systemic importance of the SCFAs and other compounds they produce are 
like hormones and the gut flora itself appears to function like an endocrine organ, ${ }^{[7]}$ and dysregulation of the gut flora has been correlated with a host of inflammatory and autoimmune conditions. ${ }^{[4][8]}$

\section{Gut-brain integration:}

The gut-brain axis, a bidirectional neurohumoral communication system, is important for maintaining homeostasis and is regulated through the central and enteric nervous systems and the neural, endocrine, immune, and metabolic pathways, and especially including the hypothalamic-pituitary-adrenal axis (HPA axis). ${ }^{[1]}$ That term has been expanded to include the role of the gut flora as part of the "microbiome-gut-brain axis", a linkage of functions including the gut flora. ${ }^{[1][3][2]}$ The gut flora can produce a range of neuroactive molecules, such as acetylcholine, catecholamines, histamine, melatonin, and serotonin, which is essential for regulating peristalsis and sensation in the gut. ${ }^{[6]}$ Changes in the composition of the gut flora due to diet, drugs, or disease correlate with changes in levels of circulating cytokines, some of which can affect brain function. ${ }^{[6]}$ The gut flora also release molecules that can directly activate the vagus nerve which transmits information about the state of the intestines to the brain. ${ }^{[6]}$ Likewise, chronic or acutely stressful situations activate the hypothalamic-pituitary-adrenal axis, causing changes in the gut flora and intestinal epithelium, and possibly having systemic effects. ${ }^{[6]}$ Additionally, the cholinergic antiinflammatory pathway, signaling through the vagus nerve, affects the gut epithelium and flora. ${ }^{[6]}$ Hunger and satiety are integrated in the brain, and the presence or absence of food in the gut and types of food present, also affect the composition and activity of gut flora. ${ }^{[6]}$

\section{Anxiety and mood disorders:}

As of January 2016 work on the relationship between gut flora and anxiety disorders and mood disorders including depression was at an early stage, with insufficient evidence to draw conclusions about a causal role for gut flora changes in these conditions, nor for the efficacy of any probiotic treatment. ${ }^{[9]}$ People with anxiety and mood disorders tend to have GI problems; small studies have been conducted to compare the gut flora of people with major depressive disorder and healthy people, but those studies have had contradictory results. ${ }^{[9]}$ Much interest was generated in the potential role of gut flora in anxiety disorders, and more generally in the role of gut flora in the gutbrain axis, by studies published in 2004 showing that germ-free mice have an exaggerated HPA axis response to stress caused by being restrained, which was reversed by colonizing their gut with a Bifidobacterium species. ${ }^{[2]}$

\section{Schizophrenia:}

People with schizophrenia tend to also have GI problems, ${ }^{[6]}$ but as of 2015 , no studies had been carried out to compare the gut flora of people with schizophrenia with healthy people. ${ }^{[3]}$ Research causing schizophrenia-like symptoms in mice by giving them phencyclidine (PCP) has found changes to the gut flora of the treated mice compared with untreated mice. ${ }^{[3]}$

\section{Autism:}

Around $70 \%$ of people with autism also have GI problems, and autism is often diagnosed at the time that the gut flora becomes established, indicating that there may be a connection between autism and gut flora. ${ }^{[10]}$ Some studies have found differences in the gut flora of children with autism compared with normal children - most notably elevations in the amount of Clostridium in the stools of children with autism compared with the stools of the children without ${ }^{[11]}$ - but these results have not been consistently replicated. ${ }^{[10]}$ Many of the environmental factors thought to be relevant to the development of autism would also affect the gut flora, leaving open the question whether specific developments in the gut flora drive the development of autism or whether those developments happen concurrently. ${ }^{[3][10]}$ As of 2016, studies with probiotics had only been conducted with animals; studies of other dietary changes to treat autism have been inconclusive. ${ }^{[9]}$

\section{Parkinson's disease:}

As of 2015 one study had been conducted comparing the gut flora of people with Parkinson's disease to healthy controls; in that study people with Parkinsons had lower levels of Prevotellaceae and people with Parkinsons who had higher levels of Enterobacteriaceae had more clinically severe symptoms; the authors of the study drew no conclusions about whether gut flora changes were driving the disease or vice versa. ${ }^{[3]}$

\section{Method:-}

The gut-brain axis, a bidirectional neurohumoral communication system, is important for maintaining homeostasis and is regulated through the central and enteric nervous systems and the neural, endocrine, immune, and metabolic pathways, and especially including the hypothalamic-pituitary-adrenal axis (HPA axis). The gut flora also release 
molecules that can directly activate the vagus nerve which transmits information about the state of the intestines to the brain. Mood disorders, Schizophrenia, Autism, and Parkinson's disease are the specific conditions which associates with gut-brain-axis. This review is to identify and summarize the existing evidences on association between gut brain axis and various disorders. Studies were identifies by using following database.Pubmed,

Google scholar, Embase, Cochrane, Pedro and Medline

\section{Review of Literature}

\begin{tabular}{|c|c|c|c|c|c|}
\hline S.NO & AUTHOR & TITLE & YEAR & METHODOLOGY & CONCLUSION \\
\hline 1. & $\begin{array}{l}\text { Caso. JR, Balanza } \\
\text { Martinez. V, Palomo. } \\
\text { T, Garcia Bueno. B }\end{array}$ & $\begin{array}{l}\text { The microbiota and } \\
\text { gut brain axis: } \\
\text { contributions to } \\
\text { immunopathogenesi } \\
\text { s of schizophrenia }\end{array}$ & 2016 & $\begin{array}{l}\text { Considering the study on } \\
\text { microbiome and several } \\
\text { research shows the potential } \\
\text { role of gut microbiota on } \\
\text { various neurologic and } \\
\text { psychiatric conditions. The } \\
\text { aim is to study the possible } \\
\text { effect of these organisms in } \\
\text { immunopathogenesis } \\
\text { schizophrenia. }\end{array}$ & $\begin{array}{l}\text { It is to conclude that } \\
\text { the following research } \\
\text { needs to improve } \\
\text { certain advancements } \\
\text { in personalized } \\
\text { medicine and the } \\
\text { future research should } \\
\text { include several } \\
\text { microbiota and certain } \\
\text { therapies in order to } \\
\text { improve symptoms } \\
\text { and to decrease } \\
\text { immue dysfunction in } \\
\text { patient wath } \\
\text { schizophrenia. }\end{array}$ \\
\hline 2. & $\begin{array}{l}\text { Hu. X, Wang. T, Jin. } \\
\text { F }\end{array}$ & $\begin{array}{l}\text { Alzheimer's disease } \\
\text { and gut microbiota }\end{array}$ & 2016 & $\begin{array}{l}\text { The host brain function and } \\
\text { cognitive behavior can be } \\
\text { modulated by gut microbiota } \\
\text { via microbiota-gut brain axis. } \\
\text { The alterations in host } \\
\text { cognitive behaviour, gut } \\
\text { microbiota and gut } \\
\text { physiology will increasing or } \\
\text { decreasing risks of AD. Gut } \\
\text { microbiota disturbance can } \\
\text { induce increased } \\
\text { permeability of intestine and } \\
\text { blood brain barrier and it will } \\
\text { raise the incidence of } \\
\text { neurodegeneration disorder. } \\
\text { The onset of AD support the } \\
\text { hygiene hypothesis. }\end{array}$ & $\begin{array}{l}\text { All the results suggest } \\
\text { that } \mathrm{AD} \text { is closely } \\
\text { related to the } \\
\text { imbalance of gut } \\
\text { microbe and it may } \\
\text { begin in the gut. The } \\
\text { personalized diet or } \\
\text { intervention will } \\
\text { probably become a } \\
\text { new treatment for } \\
\mathrm{AD}{ }^{[13]}\end{array}$ \\
\hline 3. & $\begin{array}{l}\text { Maqsood. R, Stone. } \\
\text { TW }\end{array}$ & $\begin{array}{l}\text { The gut brain axis, } \\
\text { BDNF, NMDA and } \\
\text { CNS disorders }\end{array}$ & 2016 & $\begin{array}{l}\text { This review mainly focuses } \\
\text { on the influence of GI tract } \\
\text { on BDNF and its relationship } \\
\text { with receptors for (N-methyl- } \\
\text { D-aspartate) which is } \\
\text { associated with the } \\
\text { development } \\
\text { schizophrenia and other } \\
\text { psychopathologies, as these } \\
\text { are believed to be involved in } \\
\text { synaptic plasticity and } \\
\text { cognitive function. GI } \\
\text { microbiota will contribute to } \\
\text { the pathophysiology of } \\
\text { BDNF induced NMDAR } \\
\text { dysfunction which is relevant }\end{array}$ & $\begin{array}{l}\text { The changes in the gut } \\
\text { microbiota by using } \\
\text { probiotics, prebiotics } \\
\text { or antimicrobial drugs } \\
\text { has been found } \\
\text { promising as a } \\
\text { therapeutic measure to } \\
\text { counteract } \\
\text { behavioural deficits } \\
\text { which is useful to } \\
\text { supplement the } \\
\text { actions of drugs in the } \\
\text { treatment of CNS } \\
\text { disorders. }\end{array}$ \\
\hline
\end{tabular}




\begin{tabular}{|c|c|c|c|c|c|}
\hline & & & & $\begin{array}{l}\text { to developing novel } \\
\text { therapeutics for } \\
\text { schizophrenia and other } \\
\text { related disorder. The central } \\
\text { BDNF levels are reduced } \\
\text { during the absence of GI } \\
\text { microbes and this inhibits the } \\
\text { maintenance of NMDAR } \\
\text { production. The disinhibition } \\
\text { of glutametergic output will } \\
\text { disrupts the central signal to } \\
\text { noise ratio and leads to } \\
\text { aberrant synaptic behaviour } \\
\text { and cognitive deficits. The } \\
\text { BDNF function in the CNS } \\
\text { can be modulated by gut } \\
\text { microbiota via changes in } \\
\text { neurotransmitter function by } \\
\text { affection modulatory } \\
\text { mechanisms such as the } \\
\text { Kyneurenine pathway, or by } \\
\text { changes in actions of short } \\
\text { chain fatty acids in brain. }\end{array}$ & \\
\hline 4. & $\begin{array}{l}\text { Cepeda. MS, Katz. } \\
\text { EG and Blacketer. C }\end{array}$ & $\begin{array}{l}\text { Microbiome-Gut } \\
\text { brain axis: } \\
\text { Probiotics and their } \\
\text { association with } \\
\text { depression }\end{array}$ & 2016 & $\begin{array}{l}\text { A large population based } \\
\text { cross sectional study was } \\
\text { conducted by National health } \\
\text { to assess the association of } \\
\text { probiotics with depression. } \\
\text { During interview days they } \\
\text { consume any probiotic food } \\
\text { or supplement and the } \\
\text { subjects were classified as } \\
\text { depressed if patient health } \\
\text { questionare scores were } \\
\text { greater than or equal to } 10 . \\
\text { Unadjusted analysis suggest } \\
\text { the subjects those who } \\
\text { consume probiotics had } \\
\text { lower adds of depression and } \\
\text { after adjustment the effect } \\
\text { was attenuated. }\end{array}$ & $\begin{array}{l}\text { As a result there is a } \\
\text { lower rate of } \\
\text { depression in the } \\
\text { national sample and it } \\
\text { should not associated } \\
\text { with the use of } \\
\text { probiotics. }\end{array}$ \\
\hline 5. & $\begin{array}{l}\text { Luna. RA, Savidge. } \\
\text { TC, Williams. KC }\end{array}$ & $\begin{array}{l}\text { The Brain-Gut- } \\
\text { Microbiome Axis: } \\
\text { what role does it } \\
\text { play in Autism } \\
\text { spectrum disorder? }\end{array}$ & 2016 & $\begin{array}{l}\text { The interactions between the } \\
\text { CNS, GI system and micro- } \\
\text { organisms that live in the GI } \\
\text { tract can be called as brain- } \\
\text { gut-microbiome axis. FGIDs } \\
\text { commonly occur in children } \\
\text { with ASD and is closely } \\
\text { associated with the signs of } \\
\text { brain-gut-microbiome axis. }\end{array}$ & $\begin{array}{l}\text { The studies suggest } \\
\text { that the gut } \\
\text { microbiome changes } \\
\text { associated with ASD } \\
\text { and with GI disorders } \\
\text { in children with ASD. } \\
\text { The following studies } \\
\text { should be treating } \\
\text { ASD behaviours with } \\
\text { novel therapies and } \\
\text { new techniques for } \\
\text { identifying } \\
\text { disorders in children } \\
\text { with ASD. }\end{array}$ \\
\hline 6. & Kennedy PJ, Cryan & & & & \\
\hline
\end{tabular}




\begin{tabular}{|c|c|c|c|c|c|}
\hline & $\begin{array}{l}\text { JF, Dinan } \\
\text { TG, Clarke G }\end{array}$ & $\begin{array}{l}\text { Kynurenine pathway } \\
\text { metabolism and the } \\
\text { microbiota-gut-brain } \\
\text { axis }\end{array}$ & 2016 & $\begin{array}{l}\text { Kynurenine pathway } \\
\text { metabolism focuses mainly } \\
\text { on structural and functional } \\
\text { dynamics of gut microbiota } \\
\text { and signaling pathway of } \\
\text { brain gut axis. It is regulated } \\
\text { by microbial control of } \\
\text { neuroendocrine function and } \\
\text { components of immune } \\
\text { system. }\end{array}$ & $\begin{array}{l}\text { As a result, the gut } \\
\text { microbiota represents } \\
\text { a tractable target to } \\
\text { modulate the } \\
\text { kynurenine pathway } \\
\text { metabolism. }\end{array}$ \\
\hline 7. & $\begin{array}{l}\text { Santocchi } \\
\text { E, Guiducci } \\
\text { L, Fulceri F, Billeci } \\
\text { L, Buzzigoli } \\
\text { E, Apicella } \\
\text { F, Calderoni } \\
\text { S, Grossi E, Morales } \\
\text { MA, Muratori F }\end{array}$ & $\begin{array}{l}\text { Gut to brain } \\
\text { interaction } \\
\text { Autism in } \\
\text { Disorders: } \\
\text { randomized a } \\
\text { controlled trial on } \\
\text { the role of probiotics } \\
\text { on clinical, } \\
\text { biochemical ad } \\
\text { neurophysiological } \\
\text { parameters }\end{array}$ & 2016 & $\begin{array}{l}\text { A group of } 100 \text { preschoolers } \\
\text { with ASD can be classified } \\
\text { into two } \\
\text { groups and it will be } \\
\text { randomized } 1: 1 \text { to regular } \\
\text { diet with probiotics or with } \\
\text { placebo for six month. After } \\
\text { six months from baseline in } \\
\text { order to evaluate the possible } \\
\text { changes in: (1) GI symptoms; } \\
\text { (2) autism symptoms } \\
\text { severity; (3) affective and } \\
\text { behavioral comorbid } \\
\text { symptoms; (4) plasmatic, } \\
\text { urinary and fecal biomarkers } \\
\text { related to abnormal intestinal } \\
\text { function; } \\
\text { neurophysiological patterns. }\end{array}$ & $\begin{array}{l}\text { As results could add } \\
\text { information to the } \\
\text { relationship between } \\
\text { phthalates levels, } \\
\text { clinical features and } \\
\text { neurophysiological } \\
\text { patterns in ASD. }\end{array}$ \\
\hline 8. & $\begin{array}{l}\text { Emge JR, Huynh } \\
\text { K, Miller EN, Kaur } \\
\text { M, Reardon } \\
\text { C, Barrett } \\
\text { KE, Gareau MG }\end{array}$ & $\begin{array}{l}\text { Modulation of the } \\
\text { microbiota-gut-brain } \\
\text { axis by probiotics in } \\
\text { a murine model of } \\
\text { inflammatory bowel } \\
\text { disease }\end{array}$ & 2016 & $\begin{array}{l}\text { DSS (5 days) was } \\
\text { administered via drinking } \\
\text { water followed by } 3 \text { or } 9 \\
\text { days of normal drinking } \\
\text { water to assess behavior } \\
\text { during active or resolving } \\
\text { inflammation, respectively. } \\
\text { Disease (weight, colon } \\
\text { length, and histology) was } \\
\text { assessed and the composition } \\
\text { of the gut microbiota was } \\
\text { characterized by using qPCR } \\
\text { on fecal pellet DNA. In a } \\
\text { subset of mice, pretreatment } \\
\text { with probiotics was started } 1 \\
\text { wk prior to commencing } \\
\text { DSS. During active } \\
\text { inflammation (8 days), mice } \\
\text { demonstrated impaired } \\
\text { recognition memory and } \\
\text { exhibited anxiety-like } \\
\text { behavior vs. }\end{array}$ & $\begin{array}{l}\text { As a resut, mood and } \\
\text { behavior are present } \\
\text { during acute } \\
\text { inflammation in } \\
\text { murine IBD and } \\
\text { associated } \\
\text { dysbiosis and that } \\
\text { these outcomes can be } \\
\text { prevented by the } \\
\text { administration of } \\
\text { probiotics. }\end{array}$ \\
\hline 9. & $\begin{array}{l}\text { Brzozowski } \\
\text { B, Mazur-Bialy } \\
\text { A, Pajdo R, Kwiecien } \\
\text { S, Bilski } \\
\text { J, Zwolinska-Wcislo } \\
\text { M, Mach }\end{array}$ & $\begin{array}{l}\text { Mechanisms by } \\
\text { which stress affects } \\
\text { the experimental } \\
\text { and rinical } \\
\text { inflammatory bowel } \\
\text { disease (IBD). Role }\end{array}$ & 2016 & $\begin{array}{l}\text { It is to provide an overview } \\
\text { of experimental and clinical } \\
\text { evidences that stress } \\
\text { activates the brain- } \\
\text { gut axis which results in a } \\
\text { mucosal mast cells activation }\end{array}$ & $\begin{array}{l}\text { It is to conclude that, } \\
\text { an increased microbial } \\
\text { load in the colonic } \\
\text { tissue, excessive } \\
\text { cytokine release and a } \\
\text { partially blunted }\end{array}$ \\
\hline
\end{tabular}




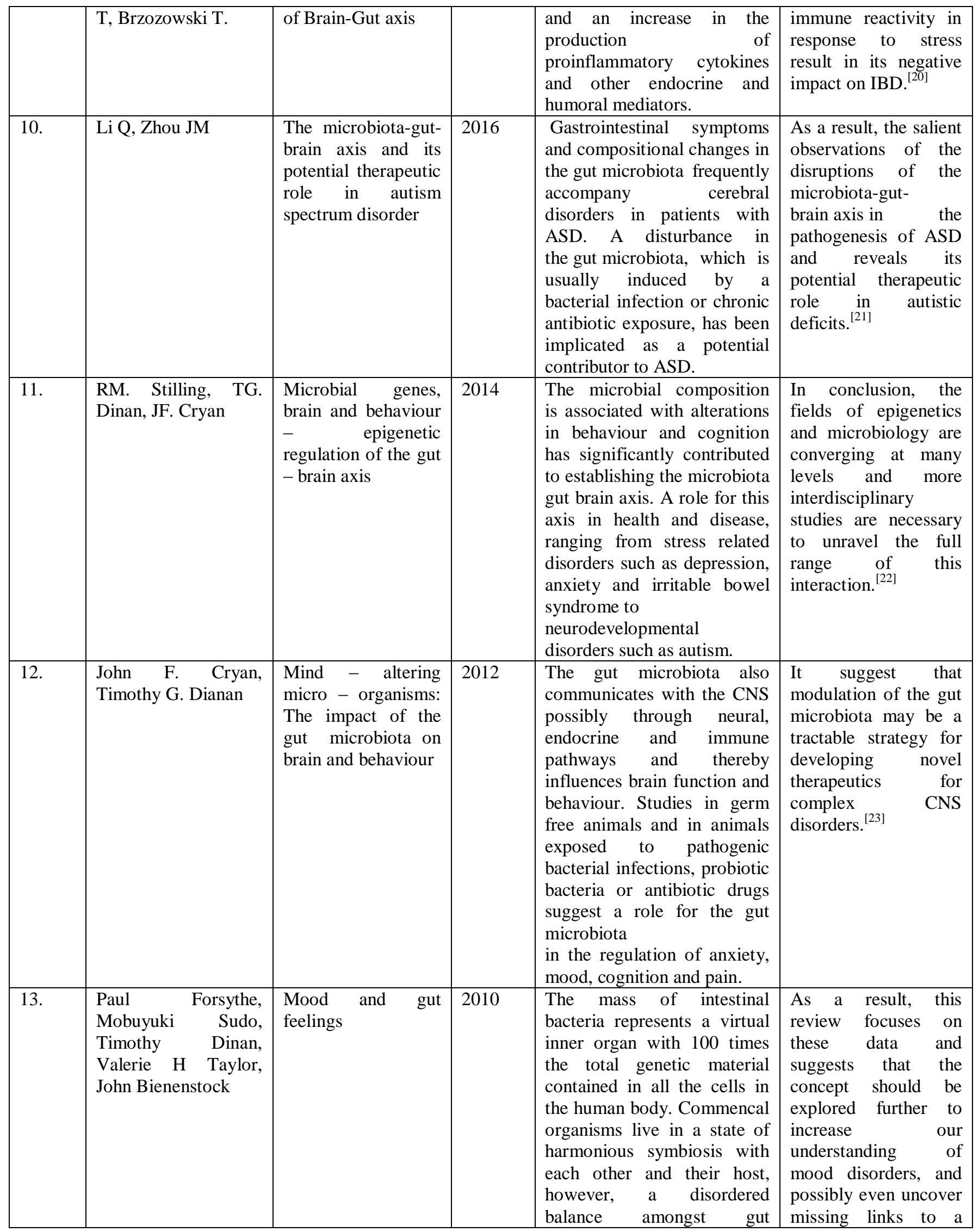




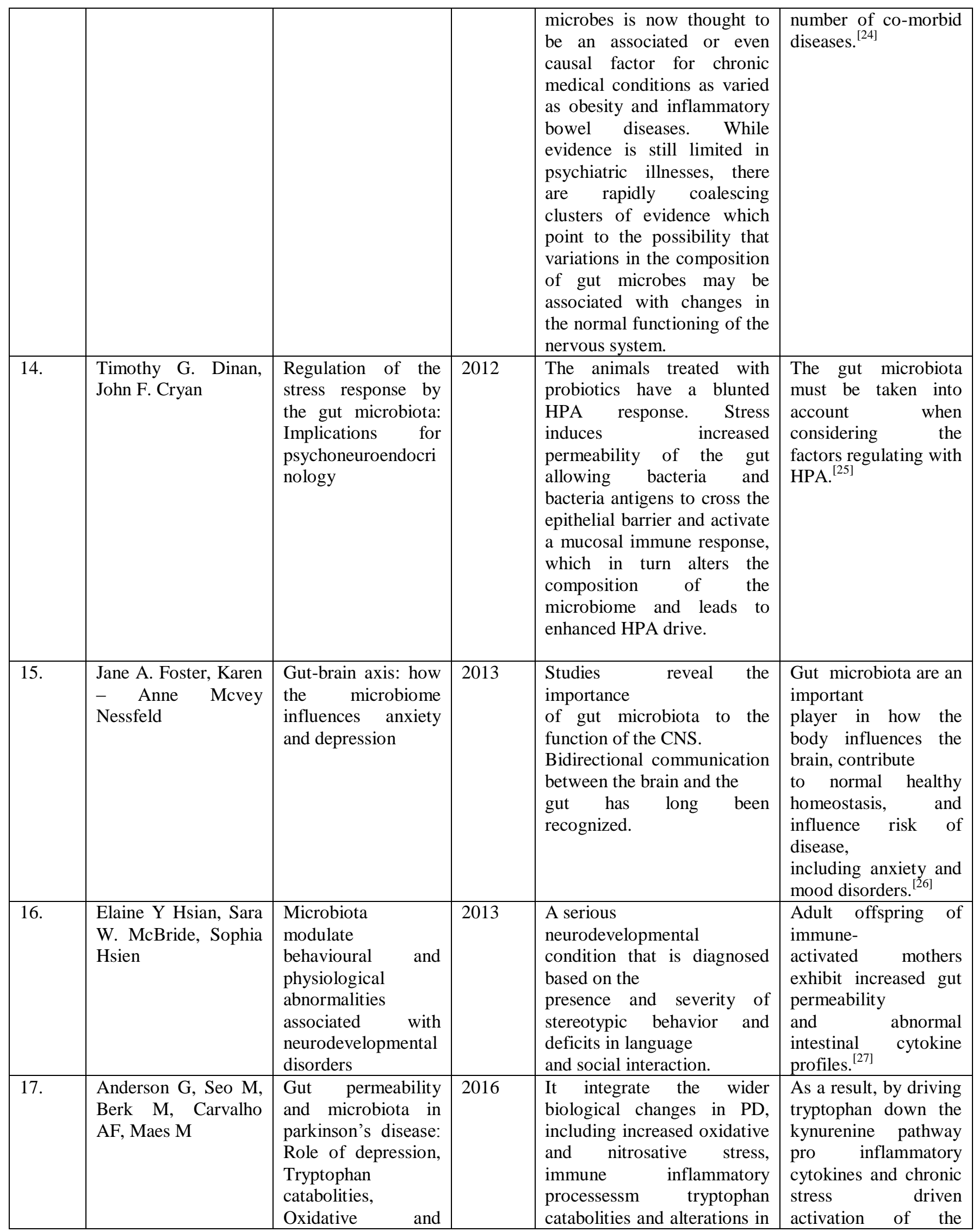




\begin{tabular}{|c|c|c|c|c|c|}
\hline & & $\begin{array}{l}\text { Nitrosative stress } \\
\text { and Melatonergic } \\
\text { pathways }\end{array}$ & & $\begin{array}{l}\text { serotoninergic and } \\
\text { melatoninergic pathways. }\end{array}$ & $\begin{array}{l}\text { hipothlamic pituitary } \\
\text { adrenal axis decrease } \\
\text { the availability of } \\
\text { serotonin as a } \\
\text { precursor } \\
\text { activation of the } \\
\text { melatonergic } \\
\text { pathways. }\end{array}$ \\
\hline 19. & \begin{tabular}{lr}
\multicolumn{2}{l}{ Karakula-Juchnowicz } \\
H, Dzikowski M, \\
Pelczarska & A, \\
Dzikowska & I, \\
Juchnowicz D &
\end{tabular} & $\begin{array}{l}\text { The brain-gut axis } \\
\text { dysfunctions and } \\
\text { hypersensitivity to } \\
\text { food antigens in the } \\
\text { etiopathogenesis of } \\
\text { schizophrenia }\end{array}$ & 2016 & $\begin{array}{l}\text { The factors which is involved } \\
\text { in the functioning of brain } \\
\text { gut axis and important for the } \\
\text { development } \\
\text { schizophrenia, i.e, } 1 \text {, } \\
\text { intestinal microbiome, } 2 . \\
\text { Permeable intestine, } 3 . \\
\text { Hypersensitivity to food } \\
\text { antigens, including gluten } \\
\text { and casein of cow's milk. It } \\
\text { indicate the probiotics, and } \\
\text { the implementation of } \\
\text { antibiotic therapy of specific } \\
\text { treatment groups. }\end{array}$ & $\begin{array}{l}\text { As a result, further } \\
\text { research is needed on } \\
\text { links between the } \\
\text { intestinal microbiome } \\
\text { and intestinal function } \\
\text { as factors mediating } \\
\text { the activation of the } \\
\text { immune system and } \\
\text { the development and } \\
\text { further course of } \\
\text { schizophrenia. }^{[30]}\end{array}$ \\
\hline 20. & $\begin{array}{l}\text { GB Rogers, DJ } \\
\text { Keating, RL Young, } \\
\text { M-L Wong, J Licinio } \\
\text { and S Wesselingh }\end{array}$ & $\begin{array}{l}\text { From gut dysiosis to } \\
\text { altered brain } \\
\text { function and mental } \\
\text { illness: mechanisms } \\
\text { and pathways }\end{array}$ & 2016 & $\begin{array}{l}\text { The potential of dysbiosis to } \\
\text { contribute } \\
\text { to psychopathology and the } \\
\text { evidence linking disruption } \\
\text { of gut } \\
\text { microbiota with specific } \\
\text { psychiatric disorders. We } \\
\text { examine the } \\
\text { role of the microbiome in } \\
\text { neurological development } \\
\text { and regulation, } \\
\text { and consider its contribution } \\
\text { to aging-related morbidity. }\end{array}$ & $\begin{array}{l}\text { As a result, the } \\
\text { potential for } \\
\text { modification of the } \\
\text { gut microbiome to } \\
\text { provide clinical } \\
\text { benefit in the context } \\
\text { of altered brain } \\
\text { function. }{ }^{[31]}\end{array}$ \\
\hline
\end{tabular}




\section{Discussion:-}

This study shows various associated disorders of the gut brain axis. As of January 2016 work on the relationship between gut flora and anxiety disorders and mood disorders including depression was at an early stage, with insufficient evidence to draw conclusions about a causal role for gut flora changes in these conditions, nor for the efficacy of any probiotic treatment. ${ }^{[9]}$ Caso et all reported about the future research should include several microbiota and certain therapies in order to improve symptoms and to increase dysfunction in patient with schizophrenia. ${ }^{[12]} \mathrm{Hu} \mathrm{X}$ et all reported that the personalized diet or intervention will probably became a new treatment for AD. ${ }^{[13]}$ Luna RA, et all reported that the following studies should be treating ASD behaviours with novel therapies and new techniques for identifying GI disorders in children with ASD. ${ }^{[16}$ Cepeda MS, et all reported that the lower rate of depression in the national sample and it should not associated with the use of probiotics. ${ }^{[15]}$ Maqsood R, et all reported that the changes in the gut microbiota by using probiotics, prebiotics or antimicrobial drugs has been found promising as a therapeutic measure to counteract behavioural deficits which is useful to supplement the actions of drugs in the treatment of CNS disorders. ${ }^{[14]}$ Kennedy PJ, et all reported that the gut microbiota represents a tractable target to modulate the kynurenine pathway metabolism. ${ }^{[17]}$ Emge JR, et all reported that the mood and behavior are present during acute inflammation in murine IBD and associated with dysbiosis and that these outcomes can be prevented by the administration of probiotics. ${ }^{[19]}$ Timothy G, et all reported that the gut microbiota must be taken into account when considering the factors regulating with HPA. ${ }^{[25]}$ Elaine Y Hsian, et all reported that the adult offspring of immune-activated mothers exhibit increased gut permeability and abnormal intestinal cytokine profiles. ${ }^{[27]}$

\section{Conclusion:-}

The reviewed article shows the various disorders of the gut brain axis. The gut microbe has been identified as the main source of highest biological variability confined in an individual and also provides constant antigenic stimulation shaping up the physiological immune response. Studies of microbiota gut brain axis could provide a deeper understanding of the relationship between the intestinal bacteria and their hosts which could help to suggest potential therapeutic strategies through affecting the composition of gut microbiota.

\section{Reference:-}

1. Wang, Y; Kasper, LH (May 2014). "The role of microbiome in central nervous system disorders". Brain Behav Immun. 38: 1-12. doi:10.1016/j.bbi.2013.12.015. PMID 2437046.

2. Jump up to: Mayer, EA; Knight, R; Mazmanian, SK; et al. (2014). "Gut microbes and the brain: paradigm shift in neuroscience" (PDF). J Neurosci. PMID 25392516.

3. Jump up to: Dinan, T.G; Cryan, 2015 (2015). "The impact of gut microbiota on brain and 662ehaviour: implications for psychiatry". Curr Opin Clin Nutr Metab Care. 18: 552-558. doi: PMID 26372511.

4. Quigley, EM (2013). "Gut bacteria in health and disease". Gastroenterol Hepatol (N Y). 9: 560-9. PMC 3983973. PMID 24729765.

5. Li,Ying; Owyang,Chung (September 2003). "Musings on the Wanderer: What's New in Our Understanding of Vago-Vagal Reflexes? V. Remodeling of vagus and enteric neural circuitry after vagal injury”. American Journal of Physiology. Gastrointestinal and Liver Physiology.

6. Petra, AI; et al. (May 2015). "Gut-Microbiota-Brain Axis and Its Effect on Neuropsychiatric Disorders With Suspected Immune Dysregulation”. Clin Ther. 37 (5): 984-95. doi:10.1016/j.clinthera.2015.04.002. PMC 4458706. PMID 26046241.

7. Clarke, G; et al. (Aug 2014). "Minireview: Gut microbiota: the neglected endocrine organ". Mol Endocrinol. 28 (8): 1221-38. doi:10.1210/me.2014-1108. PMID 24892638

8. Shen, S; Wong, CH (Apr 2016). "Bugging inflammation: role of the gut microbiota". Clin Transl Immunology. 5 (4): e72. doi:10.1038/cti.2016.12. PMC 4855262 2. PMID 27195115.

9. Schneiderhan, J; Master-Hunter, T; Locke, A (2016). "Targeting gut flora to treat and prevent disease". J Fam Pract. 65: 34-8. PMID 26845162.

10. Buie, T (May 2015). "Potential Etiologic Factors of Microbiome Disruption in Autism". Clin Ther. 37 (5): $976-$ 83. doi:10.1016/j.clinthera.2015.04.001. PMID 26046240.

11. Chen, X; D'Souza, R; Hong, ST (2013). "The role of gut microbiota in the gut-brain axis: current challenges and perspectives". Protein \& Cell. 4 (6): 403-14. doi:10.1007/s13238-013-3017-x. PMID 23686721.

12. Curr Pharm Des. 2016 Sep 6.The Microbiota and Gut-Brain Axis: Contributions to the Immunopathogenesis of Schizophrenia. Caso JR ${ }^{1}$, Balanzá-Martínez V, Palomo T, García-Bueno B. PMID: 27604609 
13. Sci China Life Sci. 2016 Aug 26.Alzheimer's disease and gut microbiota.Hu $\mathrm{X}^{1}$, Wang $\mathrm{T}^{1}$, Jin $\mathrm{F}^{2}$. PMID: 27566465 DOI:10.1007/s11427-016-5083-9

14. Neurochem Res. 2016 Aug 23.The Gut-Brain Axis, BDNF, NMDA and CNS Disorders. Maqsood $\mathrm{R}^{1}$, Stone TW2. PMID: 27553784 DOI: 10.1007/s11064-016-2039-1

15. J Neuropsychiatry Clin Neurosci. 2016 Aug 19:appineuropsych15120410.Microbiome-Gut-Brain Axis: Probiotics and Their Association With Depression. Cepeda MS ${ }^{1}$, Katz EG ${ }^{1}$, Blacketer C ${ }^{1}$. PMID: 27539375 DOI:10.1176/appi.neuropsych.15120410

16. Curr Dev Disord Rep. 2016 Mar;3(1):75-81. Epub 2016 Feb 26.The Brain-Gut-Microbiome Axis: What Role Does It Play in Autism Spectrum Disorder?Luna RA ${ }^{1}$, Savidge TC ${ }^{1}$, Williams KC ${ }^{2}$. PMID: 27398286 PMCID: PMC4933016[Available on 2017-03-01] DOI: 10.1007/s40474-016-0077-7

17. Neuropharmacology. 2016 Jul 5. pii: S0028-3908(16)30288-X. doi: 10.1016/j.neuropharm.2016.07.002. Kynurenine pathway metabolism and the microbiota-gut-brain axis. Kennedy $\mathrm{PJ}^{1}$, Cryan $\mathrm{JF}^{2}$, Dinan $\mathrm{TG}^{1}, \mathrm{Clarke}^{2}$ $\mathrm{G}^{3}$.

18. BMC Psychiatry. 2016 Jun 4;16:183. doi: 10.1186/s12888-016-0887-5. Gut to brain interaction in Autism Spectrum Disorders: a randomized controlled trial on the role of probiotics on clinical, biochemical and neurophysiological parameters. Santocchi $\mathrm{E}^{1}$, Guiducci $\mathrm{L}^{2}$, Fulceri $\mathrm{F}^{3}$, Billeci $\mathrm{L}^{2,4}$, Buzzigoli $\mathrm{E}^{2}$, Apicella $\mathrm{F}^{3}$, Calderoni $\mathrm{S}^{3}$, Grossi $\mathrm{E}^{5}$, Morales $\mathrm{MA}^{2}$, Muratori $\mathrm{F}^{3,4}$. PMID: 27260271 PMCID: PMC4893248 DOI: 10.1186/s12888-016-0887-5

19. Am J Physiol Gastrointest Liver Physiol. 2016 Jun 1;310(11):G989-98. doi: 10.1152/ajpgi.00086.2016. Epub 2016 Apr 7. Modulation of the microbiota-gut-brain axis by probiotics in a murine model of inflammatory bowel disease. Emge $\mathrm{JR}^{1}$, Huynh $\mathrm{K}^{1}$, Miller $\mathrm{EN}^{2}$, Kaur $\mathrm{M}^{2}$, Reardon $\mathrm{C}^{3}$, Barrett $\mathrm{KE}^{1}$, Gareau $\mathrm{MG}^{4}$. PMID: 27056723 DOI: 10.1152/ajpgi.00086.2016

20. Curr Neuropharmacol. 2016 Apr 4.Mechanisms by which Stress Affects the Experimental and Clinical Inflammatory Bowel Disease (IBD). Role ofBrain-Gut Axis. Brzozowski $\mathrm{B}^{1}$, Mazur-Bialy A, Pajdo R, Kwiecien S, Bilski J, Zwolinska-Wcislo M, Mach T, Brzozowski T. PMID: 27040468

21. Neuroscience. 2016 Jun 2;324:131-9. doi: 10.1016/j.neuroscience.2016.03.013. Epub 2016 Mar 8. The microbiota-gut-brain axis and its potential therapeutic role in autism spectrum disorder. Li $\mathrm{Q}^{1}, \mathrm{Zhou} \mathrm{JM}^{2}$. PMID: 26964681 DOI: 10.1016/j.neuroscience.2016.03.013

22. R.M. Stilling, T.G. Dinnan, et al (2014 Jan) Microbial genes, brain and behaviour - epigenetic regulation of the gut-brain axis

23. John F. Cryan, Timothy G. Dinan et al Mind - altering micro-organisms: The impact of the gut microbiota on brain and behaviour

24. Paul Forsythe, Mobuyuki Sudo, et al (May 2009) Mood and gut feelingsTimothy G. Dinan, John F. Cryan et al (Sep 2012) Regulation of the stress response by the gut microbiota: Implications for psychoneuroendocrinology

25. Jane A. Foster, Karen-Anne Mcvey Neufeld et al (May 2013) Gut-brain axis: how the microbiome influences anxiety and depression

26. Elaine Y. Hsiao, Sara W. McBride, et al Microbiota Modulate Behavioral and Physiological Abnormalities Associated with Neurodevelopmental Disorders

27. Anderson, George; Seo, et al (Nov 2016) Gut Permeability and Microbiota in Parkinson's Disease: Role of Depression, Tryptophan Catabolites, Oxidative and Nitrosative Stress and Melatonergic Pathways

28. A. Kohler, Cristiano; Maes, et al (Nov 2016) The Gut-Brain Axis, Including the Microbiome, Leaky Gut and Bacterial Translocation: Mechanisms and Pathophysiological Role in Alzheimer's Disease

29. Hanna Karakula-Juchnowicz, Michal Dzikowski, et al (2016) The brain-gut axis dysfunctions and hypersensitivity to food antigens in the etiopathogenesis of schizophrenia

30. GB Rogers, DJ Keating et al (Apri 2016) From gut dysiosis to altered brain function and mental illness: mechanisms and pathways. 